\title{
Appraising the Implementation of Internal Marketing in a Sample of Egyptian Five-star Hotels
}

\author{
Ashraf Tag-Eldeen, $P h D$ \\ Lecturer, Faculty of Tourism and Hotels \\ Alexandria University, Egypt \\ Osman Ahmed El-said \\ Assistant Lecturer, Faculty of Tourism and Hotels \\ Alexandria University, Egypt
}

\begin{abstract}
$\underline{\text { Abstract }}$
Internal marketing has been discussed in management and academic literature. Yet, it remains poorly operationalized. This article tends to develop a clear understanding of the concept based on the academic literature, develop an instrument to measure it, and finally assess the empirical evidence of its impact on performance. The current conceptualization of internal marketing is explored in a survey among frontline employees of five-star hotels in Egypt. The classic four dimensions of internal marketing concept will be examined and assessed. These dimensions include the establishment of a service culture, the development of a marketing approach to human resource management, the dissemination of marketing information to employees and the implementation of a reward and recognition system. Thus, it can be established that employees can be a foundation of competitive advantage if the principles of internal marketing are implemented as the quality of service and customer satisfaction are influenced considerably by the values and actions of hotel employees. Moreover, hospitality managers could benefit from these findings by adapting strategies which engage and retain effective, devoted, and satisfied employees on one hand, and implementing internal marketing principles, on the other hand. The more allocation of resources towards internal marketing implementation, the higher the probability of the organization's success will be.
\end{abstract}

Keywords: internal marketing; impact on performance, marketing approach, service quality; and organizational culture. 


\section{Background}

Gronroos (1982), the scholar who introduced the term "internal marketing", defined it as the behavior of selling a corporation to its internal customers (employees). Under this principle, highly satisfied employees will help create a market-oriented and customer-centered corporation, which will consequently encourage employees with customer-oriented awareness (Bernstein 2005; Longbottom OsseoAsare Chourides and Murphy 2006). Further, Berry (1981: 25) elaborated upon the term internal marketing as "viewing employees as internal customers, viewing jobs as internal products that satisfy the needs and wants of these internal customers while addressing the objectives of the organization". Internal marketing "is attracting, developing, motivating, and retaining qualified employees through job-products that satisfy their needs. Internal marketing is the philosophy of treating customers - indeed, "wooing employees ... and is the strategy of shaping job products to fit human needs" (Parasuraman Zeithaml and Berry 1991: 151).

In the same vein, Kale (2010) revealed the importance of internal marketing by stating that recruiting and retaining quality employees in a service establishment requires designing job products that attract, develop, and motivate the right kind of employees. This requires an understanding of the internal customer's aspirations, attitudes, and concerns. Such understanding develops market research, experience, and constant communication across all levels within an organization. Additionally, Turkoz and Akyol (2008) explained that internal marketing is a planned effort using a marketing-like approach to motivate, educate and coordinate internal customers (employees) towards creating satisfaction for the external customers and as a result, increase the businesses' performance.

Gronroos (1982) in the development of internal marketing stressed the importance of remaining within marketing-type techniques to satisfy the needs, or else there will be no internal marketing. The internal customer orientation, previously mentioned, is a process that attempts to fulfill this goal where every member is treated both as a customer and supplier to the firm (Lings 1999). It is accomplished through the execution of external marketing techniques, where the focus is mainly on satisfying the product needs of the employees (Foreman and Money 1995). Internal marketing itself

incorporates marketing, management, quality control, communications, and human resource departments in order to implement the program (Varey and Lewis 1999). The incentive for 
proper implementation of internal marketing is how it will assist in the creation of a competitive advantage (Ballantyne 2003; Lings 1999). Moreover, Gronroos (1994: 14) stated, "Without active and continuous internal marketing efforts the interactive marketing impact on customers will deteriorate, the service quality will suffer and the customers will defect." The challenge for organizations is to implement these techniques but often abandon the idea through the inability to recognize immediate results (Crosby and Johnson 2003). Internal marketing exists through employees, organizations, external customer satisfaction, and cross-functional units, which all require communication for success (Ballantyne 2003).

Recently, Longbottom et al. (2006) stated that internal marketing, which is derived from marketing management in the service industry, emphasizes that organizations should treat, value, and respect employees from an internal customer's perspective to attract, develop, motivate, and retain qualified employees. Moreover, Kusluvan Kusluvan Ilhan and Buyruk (2010) stated that internal marketing views all employees as customers-including other employees and departments in the organization to whom employees are also internal suppliers. This internal marketing approach asserts that to deliver quality service and satisfy external customers, internal customers themselves should be satisfied and motivated. Internal customers should be satisfied not only with their employment conditions and the organization's human resource management practices, but also with the internal services that they receive from co-workers during service delivery (Kusluvan et al. 2010).

The relevance of internal marketing to service operations rests on the increased emphasis on service quality in customer oriented corporations. Customers no longer simply purchase products; they co-produce in service organizations (Prahalad and Ramaswamy 2000). This places greater emphasis on the process where each member must feel responsible for the outcome (Manville and Ober 2003). Service industry organizations now recognize the importance of quality and attempt to exceed the expectations of the customers (Ballantyne Christopher and Payne 1995). Since the level of perception varies from customer to customer, and since the service quality provided increases the value for the customer experience, the implementation of an internal marketing program is a main method for obtaining this level (Ballantyne et al. 1995). It is believed that organizational problems are internal, not external (Lings 1999), therefore, implementation of an internal marketing program will eliminate

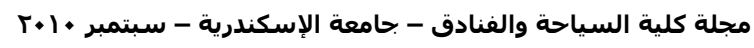


departmental walls, integrate members organization wide (Ahmed and Rafiq 2003).

Calls have been made for research to develop a single clear understanding of internal marketing, a suitable instrument for measuring it, and a serious empirical fieldwork to assess its impact (Bansal Morris and Basu 2001). The internal marketing plan must be implemented by top management, human resources, and marketing, and must also be supported by all areas. Crosby and Johnson (2003) described the importance of leadership and the need for these individuals to "walk the talk", to understand the reality of the workplace through hands on assistance, and to understand the effects on profitability of a successful internal marketing campaign.

For proper implementation to occur the focus must evolve around frontline employees. The process must start with senior leadership and a proper physical environment. The best method to influence employees involves strategic awards, other incentives, and individual empowerment to make decisions without the assistance of the upper management (Ahmed Rafiq and Saad 2002). Ballantyne (2003) stated that a successful internal marketing campaign satisfies the interests of the individual member and organization. Therefore, mutual value must exist, must be transparent and fairly perceived, must be co-created through interaction, and must increase continuously. The difference between this and the external marketing is the fact that it is co-created continually over time. If these ideas are properly implemented, positive consequences will definitely result.

Concerning the measurement of internal marketing implementation many attempts had been made by researchers stating different dimensions to measure the concept, among them are Parasuraman et al. (1991) who grouped these dimensions into; compete for talent, offer a vision and provide a purpose to equip employees with skills and knowledge of their roles, bring people together as a team, leverage the freedom factor, nurture achievement through measurements and rewards and base job design decisions on research. Another attempt by Ballantyne et al. (1995) grouped these dimensions into staff selection, training design and measurement of competency, strategic rewards, staff climate monitors, internal communications and support for quality improvement.

According to Hogg Carter and Dunne (1998) dimensions of internal marketing measurement is; communication, staff training, appraisal 
and feedback, and customer consciousness. Alternatively, Varey and Lewis (1999) differentiated these dimensions into; dissemination of information from all internal groups; development of competence, and development of incentive and motivation systems. Ahmed and Rafiq (2003) distinguished these dimensions into; strategic rewards, internal communications, training and development, organizational structure, senior leadership, physical environment, staffing, selection and succession, inter-functional coordination, incentive systems, empowerment and operational/process changes. Moreover, Tsai and Tang (2008) identified key elements of internal marketing, including service training programs, performance incentives, and vision for service excellence.

Recent literature has emphasized the importance of the internal marketing of service organizations. Internal marketing is important to organizations because it is related to employees' job satisfaction and organizational commitment (Makanjee Hartzer and Uys 2006; Chang and Chang 2007; Trimble 2006; Kudo Satoh Hosoi Miki Watanabe and Kido 2006; Sihombing and Gustam 2007; Farzad Nahavandi and Caruana 2008; Ting 2010). Furthermore, Chang and Chang (2009) study results in the health sector indicated that the hospital managers need to recognize the importance of internal marketing for staff retention and the survival of their organizations as competitive pressure increases.

The complexity of the tourism and hospitality industries and their employment structures and labor market characteristics, makes the management of people difficult and different from many other industries. A growing number of studies confirmed the importance of internal marketing in the hotel and hospitality industry. For example, Lo Stalcup and Lee (2010) conducted a study on Chinese hotels and stated that in order to build good relations with customers; hotel operators must address employee's needs, firstly. CastellanosVerdugo and Veerapermal (2009) suggested that a wide range of measures should be used by hotel managers in order to develop and maintain employee-customer relationship quality. Additionally, Turkoz and Akyol (2008) found a positive relationship between internal marketing and the dimensions of hotel performance which indicated that a high level of internal marketing leads to a higher level of hotel performance, and a low level of internal marketing produces a lower level of hotel performance. In the hospitality industry the concept of internal marketing was developed to help firms create 
customer consciousness and motivation for interactive marketing throughout the organization.

Moreover, Wildes (2005) provided evidence that increasing internal service quality given to restaurant workers resulted in higher employee satisfaction, reduced employee turnover, and an increase in employees' recommending their jobs to others. Similarly, Arnett, Laverie, and McLane (2002) demonstrated that internal marketing strategies in the hotel industry contributed to both job satisfaction and pride in the organization, which both resulted in an increase in positive employee behavior, including well service, cooperation with other employees, and commitment to the organization. In the airline industry, the internal marketing practices of Southwest Airlines were found to be responsible for extremely happy, motivated, and productive employees who contributed to excellent customer service, competitive advantage, and organizational performance in terms of profits, market share, safety records, and cost reduction (O'Reilly and Pfeffer 2000).

\section{Research Questions}

The present research aims at testing the propositions cited in the following questions:

1. Are internal marketing principles implemented in Egyptian fivestar hotels from the viewpoint of frontline employees and the extent to which these different principles are implemented?

2. Is there any difference between satisfied and unsatisfied employees in their perceptions of internal marketing implementation and does the employees' age have any definite impact on their perceptions of internal marketing implementation?

3. Are there any apparent differences in the perceptions of the internal marketing implementation among different categories of experienced employees?

\section{Internal marketing dimensions}

One of the primary objectives of this research is to assess internal marketing implementation among a sample of five-star hotels in Egypt. The researchers considered evaluating Carlzon's definition of internal marketing (Carlzon 1987) while reviewing other authors' views and approaches; as that type of marketing aimed internally at the firm's employees. These steps are:

1- The establishment of a service culture.

2- The development of a marketing approach to human resource management. 
3- Information dissemination among hotel employees.

4- The implementation of a reward and recognition system.

\subsection{The establishment of a service culture}

The emphasis on culture's rule and influence in organizations has been emphasized in a wide array of literature. For instance, Deal and Kennedy (1982) highlighted that an organizational culture is the pattern of shared values and beliefs that gives members of an organization meaning, and provides them with the roles of behavior in the organization. As Schein (1999) asserted, what really drives the culture - its essence - is the learned, shared, tacit assumptions on which people base their daily behavior. He elaborated that doing the reverse is very difficult; as one cannot infer the assumptions just from observing the behaviors. Kotler (2000) indicated that organizations can achieve success through focusing on understanding the requirements of customers, generating an understanding of the marketplace and disseminating that knowledge to everyone in the firm, this leads the organization to respond effectively with innovative, competitive and differentiated products and services.

Ballantyne (2003) sponsored a different approach to implement internal marketing properly through the organizational culture issue since the organizations must understand their knowledge exchange patterns. Within this context, Ballantyne (2003) developed three patterns: (1) hierarchical exchanges, (2) inter-functional exchanges, and (3) network exchanges. These patterns are not successful on their own, but in marketing where relationships are vital, the use of each exchange process impacts on internal marketing (Ballantyne 2003). The implementation of internal marketing through these exchange processes demonstrates how service quality may not be isolated from the external customers. This is especially true in service organizations where frontline employees represent most of the contact with customers (Wasmer and Gordon 1991). Internal marketing began as a method to motivate and satisfy employees, developed through a customer orientation phase, and now is an essential method for the recognition and implementation of change (Ahmed and Rafiq 2003) but it gains legitimacy when external market relevance exists (Ballantyne 2003).

In a more practical approach, Lewis (1991) asserted that for a company to be successful with internal marketing, it needs to follow four procedures; recruit and select the right people, offer them an

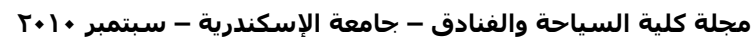


appropriate package of employment, welfare, and rewards, train them to enhance their skills and to encourage a consumer orientation and supervise and evaluate their performance. The idea is that the interaction between management and staff needs to be managed before success can be achieved by the interaction between staff and the consumer.

Further, Arnette Laverie and Mclane (2002) suggested that in order to achieve a good internal marketing strategy managers have to alter the culture of their organization by; hiring employees who fit well with the organization's mission, training the employees in skills that match this mission and motivating employees to adopt actions and attitudes that are consistent with this mission. According to Arnette et al. (2002) successful internal marketing programs can lead to important payoffs to the organization such as lower employee turnover rates, increase in service quality, high level of employee satisfaction and an improved ability to implement change in the organization. The general idea of internal marketing concept is that organizations that serve their employees (or internal customers) well have a positive effect on their external customers (Hallowell Schlesinger and Zornitsky 1996). Internal marketing is thought to help develop, motivate, and retain customer-conscious employees. Lewis (1991: 33) asserted that "by satisfying the needs of its internal customers, an organization upgrades its capability of satisfying the needs of its external customers".

\subsection{The development of a marketing approach to human resource management}

According to Carlzon (1987) managers must use the principles of marketing in order to attract and retain employees. They must research and develop an understanding of their employees' needs, just as they examine the needs of the customers. According to Carlzon (1987), not all employees are equal as some of them seek money to supplement their income, while others seek work to be their sole source of income.

Moreover, Sirakaya Kerstetter and Mount (1999) and Robertson (1994) reported that hospitality jobs possess multiple attributes and require particular characteristics that define particular jobs and distinguish them from alternatives. Therefore, the selection process of hospitality employees plays an important role in determining a person's overall performance and commitment to an organization. They added that employers in the hospitality industry always have struggled to find the "right type of employee" for frontline jobs: an 
individual who has the type of personality, motivation, and skills that successfully contribute to customer satisfaction and the attainment of the firm's overall objectives. Successful companies with a strong service orientation understand the role that employees play in the overall satisfaction of their customers and thus place greater importance on identifying the types of people who are committed to pleasing the customer (Sirakaya et al. 1999).

Therefore, all service-oriented companies within the hospitality industry must develop proactive procedures to identify the "right" types of employees who (a) have a service orientation, and (b) actively pursue situations (jobs) that would enable them to create caring, friendly, and warm relationships with customers to satisfy their inner needs. Ultimately, matching the right people with the right job might increase job satisfaction, thereby improving the likelihood of successful service encounters. Furthermore, Bell and Zemke (1992) identify three universal role requirements required from high contact employees. First, "great service performers must be able to create a relationship with the audience" the customer. Second, "great service performers must be able to handle pressure" and control themselves. Third, "great service performers must be able to learn new scripts" and implement them because expectations and situations are constantly changing. Based on these performance assumptions, the service provider has to be careful to implement measures to enhance the tourist customer's experience (Bell and Zemke 1992).

Within service industries, such as the hotel industry, provision of a service by an employee (production) and experience of that service by the customer (consumption) are often instantaneous (Carlzon 1987). Consequently, the behavior and attitudes of employees are critical because it is often they who determine the quality level of customer service (Susskind Borchgrevink Brymer and Kacmar 2000). The social environment of the workplace affects these employee behaviors and attitudes. Within different workplaces or industries, it has been argued that the effect of the environment on employee behavior will be typified by different sets of characteristics or dimensions. The most common method to measure work environment has been to record the perceptions of individual employees on a range of aspects of the work environment. These are then summed across sets of items to produce scores for a small number of dimensions, and then these dimension scores are aggregated across employees to obtain work environment

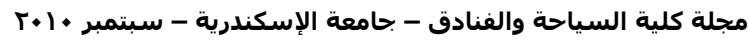


dimension scores for the organization (James Joyce and Slocum 1988).

Arnette et al. (2002) conducted a study to test the impact of effective internal marketing on positive employee behavior. They concluded that work environment and management practices had positively influenced job satisfaction and employees' behavior. Among those practices were employee empowerment which has been emphasized by Velthouse (1990), Wynne (1993) and Snipes Oswald LaTourc and Armenakis (2005) as a significant issue in service quality and customer satisfaction improvements within a service organization.

Only few studies have examined the relationship between employee feelings of empowerment and service quality. In their study of 279 hotel units, Hartline and Ferrell (1996) found that empowerment, under the appropriate conditions, increases job satisfaction and service quality. It seems logical and makes intuitive sense that allowing customer-contact employees to use their discretion in serving customers could have many positive influences on their behaviors in the service encounter (Snipes et al. 2005). They added that from an employee's perspective, feelings of empowerment should provide employees with the sense of control that is needed to make the necessary changes for service quality improvements

According to Carlzon (1987) an effective internal marketing program demands close cooperation between marketing and human resource management. A marketing approach to human resource management starts with hiring the right employees and selection methods that identify customer-oriented candidates must be used as a part of the hiring process. Moreover, organizations should follow the following steps in order to accomplish this dimension; creating positions that attract good employees, using a hiring process that identifies and results in hiring service-oriented employees, providing initial employee training designed to share the company's vision with the employee and supply the employee with product knowledge, providing continuous employee training programs and also employees must be able to maintain a positive attitude.

\subsection{Dissemination of marketing information to employees}

Communication is the means by which organizations transfer information from one entity to another, that is, disseminate information (Johlke and Duhan 2000). Consequently, it affects the 
performance of frontline staff. Information dissemination is an important prerequisite to aligning employees' attitudes and behaviors with the organization's goals (Guest and Conway 2002). Internal communications are a key in this process (Gronroos 1994). The close physical proximity between managers and employees increases opportunities for such communication, providing the chance to collect information about the wants and needs of employees, as described above, and also to disseminate information. The process of communication is also important in fostering organizational identification (Smidts Pruynt and Van Riel 2001) and subordinate job outcomes (Keller 1994). In particular, bidirectional informal communications between managers and staff have positive outcomes for frontline staff (Johlke and Duhan 2001). In the context of internal marketing orientation, this is particularly important as the close proximity of staff and their managers means that bidirectional communications constitute an important part of workplace behavior. All employees must be treated as customers; this means the creation of specifications, the creation of awareness, and the identification of expectations through market research. Organizations have to segment the employees and tailor specific strategies for each segment. The procedures implemented may be examined through staff climate monitors (Ahmed et al. 2002, Hogg et al. 1998).

Carlzon (1987) bluntly considered that the most effective way of communicating with customers is through customer-contact employees. The literature provided a large number of studies that tried to study the social interaction linkages between service employees and customers in the service sector. The employee dimension was found to be the best predictor of overall satisfied service encounter (Arnette et al. 2002; Bulgarella 2005; Carmouche and Kelly 1995 and Liljander 2000).

The staff and customer transactions in the hospitality situation are characterized by a high level of personal interaction and often a low level of supervision by senior staff, these organizations exhibit features which require an analysis of human behavior (Carmouche and Kelly 1995). Additionally, Liljander (2000) cited the importance of the interaction process in the hotel industry when he indicated that major focus in any hotel should be given to the personal linkage between the service provider and the customer. But the greatest attention should be given to the employees in direct contact with the customer and the service provider on the frontline.

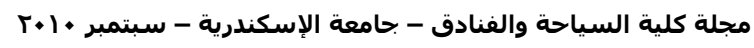


Arnette et al. (2002) added that in the hotel sector, due to the fact that most hotels rely on their employees to deliver superior service, hotel employees can be regarded as a source of competitive advantage. Service quality, customer satisfaction and loyalty are influenced considerably by the beliefs and actions of hotel employees. By providing outstanding service, hotel employees can enhance the image of the hotel and the level of perceived and actual service quality.

Another study that cites the importance of employee and customer interactions during service encounters was conducted by Bulgarella (2005) who reviewed the relationship between financial success and customer and employee variables (e.g., Customer satisfaction, employee satisfaction, etc.), He revealed that, depending on market segment and industry, between 40 and 80 percent of customer satisfaction and customer loyalty was accounted for by the relationship between employee attitudes and customer-related variables. According to Carlzon (1987) the organizations in order to implement this step should pay great attention to some important points such as; (1) the employees should be familiarized with promotions and new products through management and not through advertisements meant for external customers; (2) management at all levels must understand that employees are watching them for cues about expected behavior; (3) hospitality organizations should use printed publications as part of their internal communication; (4) hotels have to use technology and training to provide employees with product knowledge; (5) employees should receive information on new products and product changes, marketing campaigns and changes in the service delivery process.

\subsection{Implementation of a reward and recognition system}

One of the fundamental dimensions of internal marketing is the implementation of a proper reward and recognition system. Equity theory which was first proposed by Adams (1963) proposes that employees evaluate their jobs by comparing what they put into their work with what they get out of it. Huseman and Hatfield (1990) suggested that inputs (what the employee puts into the job) include an effort in the job, time, loyalty to the organization, and compliance to organizational policies. Outputs (what the employee gets out of the job), on the other hand, include pay, fringe benefits, and less tangible rewards such as status, recognition for good work, and sense of accomplishment. 
Friedman and Montanari (1980) asserted that rewarding and recognition structure has a great impact on employee behavior and organizational effectiveness. This view is supported by Guest and Conway (2002), who proposed that a psychological contract exists in which managers make promises and commitments to employees that they will receive certain rewards for displaying appropriate behaviors. Guest and Conway (2002) reported that active management of this contract has a positive impact on employee attitudes and behaviors. Fair and effective procedures coupled with the proper execution of such procedures provide a guarantee of rewards that promote exceptional employee cooperation and customer-service performance (Allan and Tyler 1988). According to Desatnick and Detzel (1993) the kinds of behaviors that should be rewarded are the job-related behaviors such as friendliness, overall quality of employee service, attentiveness, consistency, efficiency, professionalism, neat personal appearance, distinctive personality, personal recognition, genuiness, speed and customization. Desatnick and Detzel (1993) mentioned that rewards that are very effective at encouraging superior service in this industry include the following: cash bonuses; gain sharing, (with improved service and productivity employees share the gain) and profit sharing, as organizations earn more, they contribute more to profit-sharing retirement funds for employees and ownership

Additionally, Forrester (2000) argued that money counts a lot, especially for those who have little of it. Therefore, perceptions of appropriate levels of rewards and recognition systems have a significant impact on hospitality employees' job satisfaction and loyalty to their organizations (Heskett Jones Loveman Sasser and Schlesinger 1994). Organizational leaders trying to create a strong service climate should establish and consistently implement rewards for exceptional performances. Moreover, Bowen and Johnston (1999) stated that having appropriate reward policies in place is not only important for inducing employees to deliver high-quality services but also in motivating them to deal with customer complaints. An organization's reward structure has a significant impact on employee satisfaction and loyalty (Lawler 2000).

\section{Scale development and methodology \\ 4.1 Questionnaire development}

The primary objective of this research was to measure internal marketing implementation in five-star hotels and to identify the relationship between internal marketing implementation and other

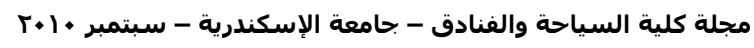


organizational factors such as age, years of experience and satisfaction level. A questionnaire scale was developed in order to address these aims. The first step in the scale development procedure was to create a pool of items designed to assess the dimensions of the internal marketing implementation outlined earlier in the literature review. First, Lings and Greenley (2005) 42-item instrument designed to measure internal marketing orientation was examined. Second, an extensive review of the literature was conducted. Information from literature review and Lings and Greenley (2005) 42-item instrument was then used to develop an instrument for measuring the implementation of internal marketing as perceived by frontline hotel employees.

The item pool was then reviewed by a panel of marketing and human resources' academics who were asked to comment on the relevance, clarity, and conciseness of each of the items and to point out some additional ways of tapping the construct. Consequently, a pool of 45 items divided between four dimensions was generated for inclusion into the survey instrument.

In addition, other questions were included in the questionnaire in order to understand the differences between different employee categories such as (age, years of experience and satisfaction level). The final questionnaire form included two sections; the first section of the questionnaire was directed to collect data related to the profile of employees such as; age, gender, social status, educational level, years of experience generally, years of working on the current job and satisfaction level. The second section of the questionnaire consisted of forty five statements distributed among four parts in order to measure the degree of implementation using a five-point scale, anchored at strongly agree and strongly disagree as (1) indicates strongly agree for items that are strongly implemented in the workplace and (5) strongly not agree for items that are strongly not implemented in the workplace while (3) denoted a neutral condition.

\subsection{Questionnaire pre-testing and pilot study}

Face validity of the questionnaire was applied through the use of a panel of five experts in the field of survey designs and academics. They were asked to review a first draft of the questionnaire and to provide feedback based on the clarity, wording, flow, completion time and the extent to which they believe the questionnaire measured what it was purported to measure. Their comments indicated the ambiguity 
of some statements and suggested the inclusion of some different measurement statements. Proper modifications have been carried out.

Then the second draft was piloted to twenty employees in order to identify questionnaire deficiencies and problems with layout and design, to get suggestions, to test the time proposed for answering the questionnaire, and to investigate the level of comprehension of the constructed questionnaire. After a review of the pilot test results and consultation with relevant experts, several changes were made.

\subsection{Questionnaire distribution and administration}

The data from the study were collected from five-star hotel employees in Egypt. From a total number of 117 five star hotels (Egyptian Hotel Association 2009); a random sample of 36 five-star hotels was selected, representing $30.7 \%$ of the population. Five questionnaires were distributed among frontline employees in each hotel counting for a total number of 180 distributed questionnaires. The final questionnaire form was distributed in August, 2010. Hotel employees were asked to return completed questionnaires to the front desk. Out of the 180 distributed questionnaires 118 questionnaires were collected, from which only 106 were valid counting for $59 \%$ of the total sample which represents a satisfying response rate.

\section{Results and Discussion}

The data for the entire study was input into the Statistical Package for Social Sciences (SPSS) 17.0 program for Windows to interpret results. Descriptive statistics were generated for the variables of interest, and a second reliability analysis of the instruments was conducted to ensure that the items properly represent each dimension. The three research questions were examined through various data analysis procedures and are individually discussed in further detail as outlined later.

\subsection{Respondents' Profile}

The demographic profile of respondents, their work experience and satisfaction level are shown in table (1). They were distributed among different age categories; of which the category ranged from 21-25 years old presented the highest percentage $(46.2 \%)$, followed by the category ranging from $26-30$ years old $(31.1 \%)$, the category from 31 35 years old $(17 \%)$, then the category from $36-40(2.8 \%)$ and finally the category above 40 years old $(2.8 \%)$. The majority of employees were male representing $(98.1 \%)$, while females only represented $(1.9 \%)$. Out of the total respondents $53.8 \%$ were single, followed by

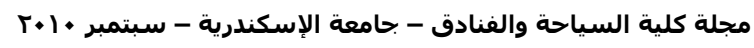


married employees (44.3\%), and other status such as engaged and divorced represented $(1.9 \%)$. Most employees received higher education $(77.9 \%)$, followed by other forms of education $(20.8 \%)$, and those who had only secondary school education represented (1.9\%).

Regarding the years of work experience in the current hotel, a high percentage of employees $(42.5 \%)$ indicated that they have been working for this hotel from 1 to 5 years, followed by those who have been working for less than 1 year $(25.5 \%)$, while $(23.6 \%)$ of employees have been working in their current hotel from 6 to 10 years and only $(8.5 \%)$ of employees mentioned that they have been working for more than 10 years. Regarding the years of experience in the field of hospitality, a large number of employees (44.3\%) indicated that they have work experience of 1 to 5 years, followed by those who have work experience from 6 to 10 years $(21.7 \%)$, while $(19.8 \%)$ of employees have been working in the field of hospitality for less than 1 year and only (14.2\%) of employees mentioned that they have hospitality work experience of more than 10 years. It is also notable that most employees were satisfied with their current job (88.7\%) while only (11.3\%) of employees indicated unsatisfied condition.

Table (1): Employees' profile and their experience and satisfaction levels

\subsection{Results presentation and discussion - Research Question \#1}

Research question number one examined the rate of internal marketing implementation according to employees' perceptions based on the four dimensions outlined earlier in the literature review and whether that implementation varies among those different dimensions.

Results presented in table (2) revealed that most employees agree that internal marketing principles are implemented in their workplace. As for the first dimension which was entitled establishment of a service culture an average of (70.4\%) of employees agreed on the existence of a service culture in their workplace, while (16.5\%) of employees indicated a neutral effect and only (13.02\%) of employees rejected the presence of a service culture in their workplace. It is apparent that the principle (A8) "I feel that I have a genuine interest in guests and communicates this personally" recorded the highest score $(79.2 \%)$ as regards its implementation in the workplace in this dimension, while the principle (A9) "Customers are at the top of hotel's structure and corporate management is at the bottom" recorded the lowest score $(58.5 \%)$ regarding its implementation in the workplace. 


\begin{tabular}{|c|c|c|c|c|c|c|c|c|}
\hline \multicolumn{9}{|c|}{ Profile of respondents } \\
\hline Age group & $\%$ & \multicolumn{2}{|c|}{$\begin{array}{l}\text { Educational } \\
\text { level }\end{array}$} & $\%$ & Gender & $\%$ & $\begin{array}{l}\text { Social } \\
\text { status }\end{array}$ & $\%$ \\
\hline 21-25 & 46.2 & \multicolumn{2}{|c|}{$\begin{array}{l}\text { Secondary } \\
\text { school }\end{array}$} & 1.9 & Male & 98.1 & Single & $\mathbf{5 3 . 8}$ \\
\hline 26-30 & 31.1 & \multicolumn{2}{|c|}{$\begin{array}{l}\begin{array}{l}\text { Higher } \\
\text { education }\end{array} \\
\end{array}$} & 77.4 & Female & 1.9 & Married & 44.3 \\
\hline 31-35 & $\mathbf{1 7 . 0}$ & \multicolumn{2}{|c|}{ Other } & 20.8 & & & Other & 1.9 \\
\hline $36-40$ & 2.8 & & & & & & & \\
\hline Above 40 & 2.8 & & & & & & & \\
\hline \multicolumn{9}{|c|}{ Experience and satisfaction levels } \\
\hline \multicolumn{2}{|c|}{$\begin{array}{l}\text { Years of work } \\
\text { Experience }\end{array}$} & $\%$ & \multicolumn{2}{|c|}{ Years of experience } & $\%$ & \multicolumn{2}{|c|}{ Satisfaction level } & $\%$ \\
\hline \multicolumn{2}{|c|}{ Less than 1 year } & 25.5 & \multicolumn{2}{|c|}{ Less than 1 year } & 19.8 & \multicolumn{2}{|c|}{ Unsatisfied } & 11.3 \\
\hline \multicolumn{2}{|l|}{ 1-5 years } & 42.5 & \multicolumn{2}{|c|}{$1-5$ years } & 44.3 & \multicolumn{2}{|l|}{ Satisfied } & 88.7 \\
\hline \multicolumn{2}{|l|}{ 6-10 years } & 23.6 & \multicolumn{2}{|c|}{ 6-10 years } & 21.7 & & & \\
\hline \multicolumn{2}{|c|}{ More than 10} & 8.5 & \multicolumn{2}{|c|}{ More than 10 years } & 14.2 & & & \\
\hline
\end{tabular}

As for the second dimension which was entitled development of a marketing approach to human resource management an average of $(61.3 \%)$ of employees agreed that there is a marketing approach to human resource management in their workplace, while $(21.5 \%)$ of employees indicated a neutral effect and only (17.36\%) of employees rejected the presence of a marketing approach to human resource management in their workplace. It is noted that the principle (B12) "My manager motivates us to work in teamwork" recorded the highest score $(79.2 \%)$ regarding its implementation in the workplace, while the principle (B11) "I feel that there is a great cooperation between marketing and human resource departments" recorded the lowest score $(51.9 \%)$ regarding its implementation in the workplace.

The third dimension which was entitled information dissemination to hotel employees indicated the lowest level of implementation among other dimensions. $(54.91 \%)$ of employees agreed that information is disseminated to them during their working hours, while $(20.11 \%)$ of employees indicated a neutral effect and (24.99\%) of employees rejected that information is disseminated to them during their working hours. In this dimension the principle (C3) "My manager informs us about upcoming events, advertisement campaigns and new 
promotions" recorded the highest score (65.1\%) regarding its implementation in the workplace, while the principle (B11) "My hotels shares the advertisements with us before they appear in the media", recorded the lowest score (36.8\%) regarding its implementation in the workplace.

The data presented for the fourth dimension which was entitled implementation of a reward and recognition system indicated the lowest level of implementation among other dimensions. Only $(55.57 \%)$ of employees accepted that there is an implemented reward and recognition system in their working environments, while (21.6\%) of employees indicated a neutral effect and (22.8\%) of employees rejected that there is an implemented reward and recognition system in their working environments. In this dimension, principles (D1) "There is a system to tell employees how they are doing" and (D3) "The results of the measurement of the service process is communicated to all employees" recorded the highest score (67\%) regarding its implementation in the workplace, while the principle (D10) "My hotel tries to accommodate the different personal needs of all its employees", recorded the lowest score (44.3\%) regarding its implementation in the workplace.

In the final analysis, results discussed above and results of ANOVA and P-value tests presented in table (3) reveal that the internal marketing dimensions (establishment of a service culture, development of a marketing approach to human resource management, information dissemination to hotel employees, implementation of a reward and recognition system) are perceived as implemented by hotel employees in Egyptian hotels although the level of that implementation varies between those different dimensions. 
Table (2): The degree of internal marketing implementation

\begin{tabular}{|c|c|c|c|c|c|c|}
\hline \multirow{3}{*}{$\begin{array}{l}\qquad *=\text { the lowest implemented, } * *=\text { the highest implemented and } \mathbf{R} \text {. = } \\
\text { A. Statements demonstrating establishment of a service culture }\end{array}$} & \multicolumn{6}{|c|}{ Degree of internal marketing implementation } \\
\hline & \multicolumn{2}{|c|}{ Implemented } & \multicolumn{2}{|c|}{ Neutral } & \multicolumn{2}{|c|}{ Not implemented } \\
\hline & $\mathbf{R}$. & $\%$ & $\mathbf{R}$. & $\%$ & $\mathbf{R}$ & $\%$ \\
\hline A1 My hotel adopts a culture that values the importance of the customer & 77 & 72.6 & 17 & 16 & 12 & 11.3 \\
\hline $\begin{array}{ll}\text { A2 } & \text { My organizational culture is directed to support serving the customer } \\
\text {. }\end{array}$ & 80 & 75.5 & 13 & 12.3 & 13 & 12.3 \\
\hline $\begin{array}{l}\text { A3 My hotel carries out customer service programs which produce satisfied } \\
\text { customer }\end{array}$ & 78 & 73.6 & 24 & 22.6 & 4 & 3.8 \\
\hline $\begin{array}{l}\text { A4 My managers have a positive attitude toward the customer and the } \\
\text { employee }\end{array}$ & 66 & 62.3 & 20 & 18.9 & 20 & 18.9 \\
\hline $\begin{array}{l}\text { A5 Every contact employee knows how to act with customers and what } \\
\text { expected from him }\end{array}$ & 83 & 78.3 & 14 & 13.2 & 9 & 8.5 \\
\hline $\begin{array}{l}\text { A6 My manager spends time talking to both customers and customer contact } \\
\text { employees }\end{array}$ & 66 & 62.3 & 22 & 20.8 & 18 & $\mathbf{1 7 . 0}$ \\
\hline $\begin{array}{l}\text { A7 My manager gives me the authority to make decisions that will solve } \\
\text { guests, problems }\end{array}$ & 76 & 71.7 & 13 & 12.3 & 17 & 16.0 \\
\hline $\begin{array}{l}\text { A8 I feel that I have a genuine interest in guests and communicates this } \\
\text { personally** }\end{array}$ & 84 & 79.2 & 12 & 11.3 & 10 & 9.4 \\
\hline $\begin{array}{l}\text { A9 Customers are at the top of the hotel's structure and corporate } \\
\text { management is at the bottom* }\end{array}$ & 62 & 58.5 & 23 & 21.7 & 21 & 20 \\
\hline Average & $\begin{array}{l}74.6 \\
6\end{array}$ & 70.44 & $\begin{array}{ll}17.5 \\
5\end{array}$ & 16.56 & 13.77 & 13.02 \\
\hline \multicolumn{7}{|c|}{ B. Statements demonstrating development of a marketing approach to human resource management } \\
\hline $\begin{array}{l}\text { I feel that my managers use the principles of marketing when attracting } \\
\text { and retaining employees }\end{array}$ & 62 & 58.5 & 30 & 28.3 & 14 & 13.2 \\
\hline $\begin{array}{l}\text { B2. I feel that my managers continuously research and develop an } \\
\text { understanding of my needs }\end{array}$ & 59 & $\mathbf{5 5 . 7}$ & 19 & 17.9 & 28 & 26.4 \\
\hline $\begin{array}{l}\text { Advertising programs are developed with prospective employees in } \\
\text { mind }\end{array}$ & 56 & 52.8 & 27 & 25.5 & 23 & 21.7 \\
\hline My hotel uses a marketing approach to develop different positions & 62 & $\mathbf{5 8 . 5}$ & 22 & 20.8 & 22 & 20.8 \\
\hline $\begin{array}{l}\text { There is a policy of hiring new employees through an extensive } \\
\text { interview process }\end{array}$ & 64 & 60.4 & 19 & 17.9 & 23 & 21.7 \\
\hline $\begin{array}{l}\text { Each new employee in my hotel must complete an intensive training } \\
\text { program plus job training }\end{array}$ & 71 & 67 & 12 & 11.3 & 23 & 21.7 \\
\hline I feel that there are chances for promotion and growth & 59 & 55.7 & 30 & 28.3 & 17 & 16 \\
\hline I feel that I joined the position that will keep me interested in my work & 65 & 61.3 & 28 & 26.4 & 13 & $\mathbf{1 2 . 3}$ \\
\hline I feel that I work in good working conditions & 62 & 58.5 & 26 & 24.5 & 18 & 17 \\
\hline When I do good work I feel full appreciation & 66 & 62.3 & 26 & 24.5 & 14 & 13.2 \\
\hline $\begin{array}{l}\text { B11. I feel that there is a great cooperation between marketing and human } \\
\text { resource departments* }\end{array}$ & 55 & 51.9 & 33 & 31.1 & 18 & 17 \\
\hline My manager motivates us to work in teamwork** & 84 & 79.2 & 8 & 7.5 & 14 & 13.2 \\
\hline I always receive information regularly about the hotel in which I work & 71 & 67.0 & 21 & 19.8 & 14 & 13.2 \\
\hline I feel familiar with all the products and services that the hotel sells & 76 & 71.7 & 15 & 14.2 & 15 & 14.2 \\
\hline Training programs are based on employees' needs & 64 & 60.4 & 22 & 20.8 & 20 & 18.9 \\
\hline Average & 65.0 & 61.3 & 22.5 & 21.25 & 18.4 & $\mathbf{1 7 . 3 6}$ \\
\hline
\end{tabular}




\begin{tabular}{|c|c|c|c|c|c|c|c|}
\hline \multirow{2}{*}{\multicolumn{8}{|c|}{ C. Statements demonstrating information dissemination to hotel employees }} \\
\hline & & & & & & & \\
\hline C1. & All employees have a better knowledge about the service offering & 62 & 58.5 & 19 & 17.9 & 25 & 23.5 \\
\hline & $\begin{array}{l}\text { All employees have a better knowledge about customers' wants and } \\
\text { needs }\end{array}$ & 56 & 52.8 & 22 & 20.8 & 28 & 26.4 \\
\hline & $\begin{array}{l}\text { My manager informs us about upcoming events, advertisement } \\
\text { campaigns and new promotions** }\end{array}$ & 69 & 65.1 & 15 & 14.2 & 22 & 20.8 \\
\hline & $\begin{array}{l}\text { All employees have a good knowledge about corporate aims and } \\
\text { strategy }\end{array}$ & 67 & 63.2 & 18 & 17.0 & 21 & 19.8 \\
\hline & $\begin{array}{l}\text { My manager meets regularly with staff members to report about issues } \\
\text { relating to the organization }\end{array}$ & 64 & 60.4 & 24 & 22.6 & 18 & 17 \\
\hline & $\begin{array}{l}\text { We have regular meetings with managers and ongoing communication } \\
\text { channels are opened }\end{array}$ & 57 & 53.8 & 32 & 30.2 & 17 & 16 \\
\hline & $\begin{array}{l}\text { My hotel uses technology and training to provide me with product and } \\
\text { service knowledge }\end{array}$ & 61 & 57.5 & 20 & 18.9 & 25 & 23.6 \\
\hline & $\begin{array}{l}\text { My manager believes that keeping employees satisfied is important as } \\
\text { keeping customers satisfied. }\end{array}$ & 55 & 51.9 & 18 & 17.0 & 33 & 31.1 \\
\hline & $\begin{array}{l}\text { Employees in my hotel are always adapted to the new products and } \\
\text { product changes, etc. }\end{array}$ & 52 & 49.1 & 23 & 21.7 & 31 & 29.2 \\
\hline C10. & $\begin{array}{l}\text { My hotel shares the advertisements with us before they appear in the } \\
\text { media* }\end{array}$ & 39 & 36.8 & 22 & 20.8 & 45 & 42.5 \\
\hline \multicolumn{2}{|r|}{ Average } & 58.2 & 54.91 & 21.3 & 20.11 & 26.5 & 24.99 \\
\hline \multicolumn{8}{|c|}{ D. Statements demonstrating implementation of a reward and recognition system } \\
\hline \multicolumn{2}{|r|}{ There is a syst } & 71 & 67.0 & 16 & 15.1 & 19 & 17.9 \\
\hline & $\begin{array}{l}\text { The communication process is designed to tell employees how they are } \\
\text { doing }\end{array}$ & 57 & 53.8 & 33 & 31.1 & 16 & 15.1 \\
\hline & $\begin{array}{l}\text { The results of the measurement of the service process are } \\
\text { communicated to all employees** }\end{array}$ & 71 & 67.0 & 16 & 15.1 & 19 & 17.9 \\
\hline D4. & Recognition is given to those who serve the customer well & 67 & 63.2 & 19 & 17.9 & 20 & 18.9 \\
\hline & $\begin{array}{l}\text { Reward systems and bonuses based on customer satisfaction scores are } \\
\text { implemented }\end{array}$ & 60 & 56.6 & 17 & 16.0 & 29 & 27.4 \\
\hline & $\begin{array}{l}\text { Managers meet with us regularly to find about our expectations of our } \\
\text { jobs. }\end{array}$ & 58 & 54.7 & 24 & 22.6 & 24 & 22.6 \\
\hline & $\begin{array}{l}\text { Our manager interacts directly with us to find out how to make us more } \\
\text { satisfied. }\end{array}$ & 58 & 54.7 & 30 & 28.3 & 18 & 17 \\
\hline & $\begin{array}{l}\text { Management make changes when employees feedback indicates that } \\
\text { they are dissatisfied }\end{array}$ & 48 & 45.3 & 25 & 23.6 & 33 & 31.1 \\
\hline D9. & My hotel is genuinely concerned with the welfare of all its employees. & 54 & 50.9 & 30 & 28.3 & 22 & 20.8 \\
\hline \multicolumn{2}{|r|}{$\begin{array}{l}\text { My hotel tries to accommodate the different personal needs of all its } \\
\text { employees* }\end{array}$} & 47 & 44.3 & 24 & 22.6 & 35 & 33 \\
\hline \multicolumn{2}{|r|}{$\begin{array}{l}\text { Managers treats all employees in a way that demonstrates that they are } \\
\text { valued }\end{array}$} & 57 & 53.8 & 18 & 17.0 & 31 & 29.2 \\
\hline \multicolumn{2}{|r|}{ Average } & 58.9 & 55.57 & 22.9 & 21.6 & 24.1 & 22.8 \\
\hline
\end{tabular}


Implemented answers include the rating 1 (strongly implemented) and 2 refers to (implemented) of the scale.

Not implemented includes the rating of 4 (not implemented) and 5 (strongly not implemented) of the scale while the rating of 3 refers to a (neutral) status.

Table (3): Comparison between internal marketing implementation dimensions as a percent of implementation

\begin{tabular}{||l|l|l|l|l||}
\hline Dimensions & $\begin{array}{l}\text { Minimu } \\
\text { m }\end{array}$ & $\begin{array}{l}\text { Maxim } \\
\text { um }\end{array}$ & Meal & $\begin{array}{l}\text { Std. } \\
\text { Deviation }\end{array}$ \\
\hline $\begin{array}{l}\text { A. Establishment of a service } \\
\text { B. culture }\end{array}$ & 25.00 & 100.00 & 70.44 & 20.21257 \\
\hline $\begin{array}{l}\text { B. Development of a marketing } \\
\text { approach to human resource } \\
\text { management }\end{array}$ & 13.33 & 100.00 & 61.3 & 22.86628 \\
\hline $\begin{array}{l}\text { C. Information dissemination } \\
\text { D. Implementation of a reward and } \\
\text { recognition system }\end{array}$ & 12.50 & 100.00 & 54.91 & 25.69715 \\
\hline ANOVA & 11.40 & 100.00 & 55.57 & 24.81714 \\
\hline p-value & 6.98 & & & \\
\hline
\end{tabular}

\section{- $\quad$ Research Question \#2}

Research question number two examined the differences in perceptions of internal marketing implementation between satisfied and unsatisfied employees. Covariance was examined firstly through the variance in means and secondly through the $\mathrm{T}$ and $\mathrm{P}$-value tests as illustrated in table (4). Results of the three tests showed that perceptions of internal marketing implementation among hotel employees were influenced by their satisfaction level. An examination of the means cells in table (4) reveals that satisfied employees in different departments perceive a higher level of internal marketing implementation in the four dimensions than those perceived by unsatisfied employees. $\mathrm{T}$ and $\mathrm{P}$-value tests presented in the same table confirmed this hypothesis. 
Table (4) Relationship between internal marketing implementation dimensions and satisfaction level in the workplace

\begin{tabular}{|c|c|c|c|c|c|c|c|}
\hline \multirow{2}{*}{ Dimensions } & \multirow[b]{2}{*}{$\begin{array}{l}\text { Satisfaction } \\
\text { level }\end{array}$} & \multicolumn{4}{|c|}{ Percent of implementation } & \multirow[t]{2}{*}{$\mathbf{t}$} & \multirow[t]{2}{*}{ p } \\
\hline & & Mean & $\begin{array}{c}\text { Std. } \\
\text { Deviation }\end{array}$ & $\underset{\text { um }}{\operatorname{Minim}}$ & $\underset{\mathbf{m}}{\operatorname{Maximu}}$ & & \\
\hline \multirow{2}{*}{$\begin{array}{l}\text { A. Establishment of a } \\
\text { service culture }\end{array}$} & Unsatisfied & 44.4433 & 13.60766 & 36.11 & 72.22 & \multirow{2}{*}{12.149} & \multirow{2}{*}{$.0001 *$} \\
\hline & Satisfied & 75.2961 & 18.17807 & 25.00 & 100.00 & & \\
\hline \multirow{2}{*}{$\begin{array}{l}\text { B. Development of a } \\
\text { marketing approach to } \\
\text { human resource } \\
\text { management }\end{array}$} & Unsatisfied & 33.4733 & 8.63104 & 16.67 & 41.67 & \multirow{2}{*}{19.383} & \multirow{2}{*}{$.0001 *$} \\
\hline & Satisfied & 71.1173 & 20.47863 & 13.33 & 100.00 & & \\
\hline \multirow{2}{*}{$\begin{array}{l}\text { C. Information } \\
\text { dissemination }\end{array}$} & Unsatisfied & 28.1250 & 14.18726 & 12.50 & 52.50 & \multirow[t]{2}{*}{15.224} & \multirow[t]{2}{*}{$.0001 *$} \\
\hline & Satisfied & 65.9309 & 23.62619 & 15.00 & 100.00 & & \\
\hline \multirow{2}{*}{$\begin{array}{l}\text { D. Implementation of a } \\
\text { reward and recognition } \\
\text { system }\end{array}$} & Unsatisfied & 29.7333 & 9.85507 & 18.20 & 47.70 & \multirow{2}{*}{16.657} & \multirow{2}{*}{$.0001 *$} \\
\hline & Satisfied & 64.9447 & 23.28098 & 11.40 & 100.00 & & \\
\hline
\end{tabular}

A comparison of means in addition to ANOVA test and p-value calculations were conducted to determine whether employees' age difference has an impact on their perceptions of internal marketing implementation. All of these were derived from the employees' scores on the survey. An examination of the means cells in table (5) reveals that employees who fall in the age category (31-35 years old) in different departments perceive the highest level of internal marketing implementation in the four dimensions than other age categories. On the other hand, employees who fall in the age category (36-40 years old) in different departments perceive the lowest level of internal marketing implementation in the four dimensions amongst other age categories. $\mathrm{T}$ and $\mathrm{P}$-value tests presented in the same table confirmed the difference between different age categories in their perception of internal marketing implementation. 
Table (5): Relationship between internal marketing implementation dimensions and age

\begin{tabular}{|c|c|c|c|c|c|c|c|}
\hline Dimensions & Age & Mean & $\begin{array}{c}\text { Std. } \\
\text { Deviation }\end{array}$ & Minimum & Maximum & ANOVA & p \\
\hline \multirow{5}{*}{$\begin{array}{l}\text { A. } \\
\text { Establishme } \\
\text { nt of a } \\
\text { service } \\
\text { culture }\end{array}$} & $21-25$ & 72.8461 & 17.88808 & 30.56 & 100.00 & \multirow{5}{*}{5.020} & \multirow{5}{*}{$.001 *$} \\
\hline & $26-30$ & 63.5527 & 22.71278 & 25.00 & 97.22 & & \\
\hline & 31-35 & 87.1922 & 13.24046 & 61.11 & 100.00 & & \\
\hline & $36-40$ & 60.1833 & 20.84812 & 36.11 & 72.22 & & \\
\hline & $\begin{array}{l}\text { Above } \\
40\end{array}$ & 64.8133 & 5.78303 & 58.33 & 69.44 & & \\
\hline \multirow{5}{*}{$\begin{array}{l}\text { B. } \\
\text { Developmen } \\
\text { t of a } \\
\text { marketing } \\
\text { approach to } \\
\text { human } \\
\text { resource } \\
\text { management }\end{array}$} & $21-25$ & 68.0957 & 19.06327 & 30.00 & 100.00 & \multirow{5}{*}{8.259} & \multirow{5}{*}{$\begin{array}{l}.0001 \\
*\end{array}$} \\
\hline & $26-30$ & 59.0403 & 25.73233 & 13.33 & 100.00 & & \\
\hline & 31-35 & 86.4822 & 11.78406 & 65.00 & 100.00 & & \\
\hline & $36-40$ & 32.2233 & 13.46958 & 16.67 & 40.00 & & \\
\hline & $\begin{array}{l}\text { Above } \\
40 \\
\end{array}$ & 49.4467 & 2.54551 & 46.67 & 51.67 & & \\
\hline \multirow{5}{*}{$\begin{array}{l}\text { C. } \\
\text { Information } \\
\text { disseminatio } \\
\text { n }\end{array}$} & $21-25$ & 63.6224 & 23.03225 & 12.50 & 100.00 & \multirow{5}{*}{4.074} & \multirow{5}{*}{$.004 *$} \\
\hline & $26-30$ & 53.1061 & 27.95106 & 15.00 & 100.00 & & \\
\hline & 31-35 & 78.1944 & 22.00945 & 35.00 & 100.00 & & \\
\hline & $36-40$ & 42.5000 & 17.32051 & 22.50 & 52.50 & & \\
\hline & $\begin{array}{l}\text { Above } \\
40\end{array}$ & 43.3333 & 14.21560 & 27.50 & 55.00 & & \\
\hline \multirow{5}{*}{$\begin{array}{l}\text { D. } \\
\text { Implementat } \\
\text { ion of a } \\
\text { reward and } \\
\text { recognition } \\
\text { system }\end{array}$} & 21-25 & 63.5918 & 23.75412 & 20.50 & 100.00 & \multirow{5}{*}{5.831} & \multirow{5}{*}{$\begin{array}{l}.0001 \\
*\end{array}$} \\
\hline & $26-30$ & $\mathbf{5 4 . 0 7 2 7}$ & 24.24295 & 11.40 & 100.00 & & \\
\hline & 31-35 & 76.3833 & 19.20356 & 45.50 & 100.00 & & \\
\hline & $36-40$ & 21.2333 & 5.25389 & 18.20 & 27.30 & & \\
\hline & $\begin{array}{l}\text { above } \\
40\end{array}$ & 40.8667 & 12.65319 & 29.50 & 54.50 & & \\
\hline
\end{tabular}

\section{- Research Question \#3}

Research question number three examined the differences in perceptions of internal marketing implementation amongst different categories of experienced employees ranging from less than one year to more than ten years of experience through; mean values, ANOVA test and P-value calculations. All of these were derived from the employees' scores on the survey. An examination of the means cells in table (6) reveals that employees who fall in the years of experience category (6-10 years) in different departments perceive the highest level of internal marketing implementation in the four dimensions than other categories. On the other hand, employees who fall in the years of experience category (1-5 years) in different departments perceive the lowest level of internal marketing implementation in the four dimensions amongst other categories. $\mathrm{T}$ and $\mathrm{P}$-value tests presented in the same table confirmed the difference between different 
years of experience categories in their perception of internal marketing implementation.

Table (6): Relationship between internal marketing implementation dimensions and length of experience period

\begin{tabular}{|c|c|c|c|c|c|c|c|}
\hline $\begin{array}{l}\text { Dimensio } \\
\text { ns }\end{array}$ & $\begin{array}{c}\text { Years of } \\
\text { experienc } \\
\text { e }\end{array}$ & Mean & $\begin{array}{c}\text { Std. } \\
\text { Deviation }\end{array}$ & Minimum & Maximum & ANOVA & p \\
\hline \multirow{4}{*}{$\begin{array}{l}\text { A. } \\
\text { Establishme } \\
\text { nt of a } \\
\text { service } \\
\text { culture }\end{array}$} & $\begin{array}{l}\text { less than } 1 \\
\text { year }\end{array}$ & 75.3981 & 16.78808 & 30.56 & 100.00 & \multirow{4}{*}{8.679} & \multirow{4}{*}{$.0001 *$} \\
\hline & $1-5$ years & 61.9981 & 20.34745 & 25.00 & 100.00 & & \\
\hline & 6-10 years & 82.6083 & 17.43239 & 36.11 & 100.00 & & \\
\hline & $\begin{array}{l}\text { more } 10 \\
\text { years }\end{array}$ & 80.9260 & 14.15914 & 58.33 & 100.00 & & \\
\hline \multirow{4}{*}{$\begin{array}{l}\text { B. } \\
\text { Developmen } \\
\text { t of a } \\
\text { marketing } \\
\text { approach to } \\
\text { human } \\
\text { resource } \\
\text { management }\end{array}$} & $\begin{array}{l}\text { less } 1 \\
\text { year }\end{array}$ & 70.8738 & 15.88670 & 45.00 & 100.00 & \multirow{4}{*}{8.561} & \multirow{4}{*}{$.0001 *$} \\
\hline & $1-5$ years & 56.4540 & 21.55389 & 13.33 & 93.33 & & \\
\hline & 6-10 years & 82.2470 & 22.29533 & 16.67 & 100.00 & & \\
\hline & $\begin{array}{l}\text { more } 10 \\
\text { years }\end{array}$ & 70.2227 & 21.55480 & 40.00 & 100.00 & & \\
\hline \multirow{4}{*}{$\begin{array}{l}\text { C. } \\
\text { Information } \\
\text { disseminatio } \\
n\end{array}$} & $\begin{array}{l}\text { less } 1 \\
\text { year }\end{array}$ & 67.1429 & 20.42189 & 27.50 & 100.00 & \multirow{4}{*}{6.059} & \multirow{4}{*}{$.001 *$} \\
\hline & $1-5$ years & $\mathbf{5 1 . 5 9 5 7}$ & 24.34147 & 15.00 & 100.00 & & \\
\hline & 6-10 years & 76.5217 & 26.02162 & 12.50 & 100.00 & & \\
\hline & $\begin{array}{l}\text { more } 10 \\
\text { years }\end{array}$ & 62.6667 & 24.43042 & 27.50 & 95.00 & & \\
\hline \multirow{4}{*}{$\begin{array}{l}\text { D. } \\
\text { Implementat } \\
\text { ion of a } \\
\text { reward and } \\
\text { recognition } \\
\text { system }\end{array}$} & $\begin{array}{l}\text { less } 1 \\
\text { year }\end{array}$ & 63.1048 & 24.26352 & 20.50 & 100.00 & \multirow{4}{*}{4.278} & \multirow{4}{*}{$.007 *$} \\
\hline & 1-5 years & 53.8702 & 22.04975 & 11.40 & 100.00 & & \\
\hline & 6-10 years & 75.2000 & 23.68958 & 22.70 & 100.00 & & \\
\hline & $\begin{array}{l}\text { more } 10 \\
\text { years }\end{array}$ & 58.3267 & 27.97454 & 18.20 & 100.00 & & \\
\hline
\end{tabular}

\section{Conclusion and implications for future research}

Results of the current study revealed that all the internal marketing dimensions are implemented in Egyptian five-star hotels (the sample under investigation). This result is in agreement with the literature and several empirical studies as presented in the literature review. Moreover, the study traced the difference in perceptions between; satisfied and unsatisfied employees, different age groups and different categories of work experience. Findings in this context confirmed the difference in perceptions between these different categories.

In conclusion, it could be established that internal marketing principles are implemented in Egyptian five-star hotels (the sample under investigation), and that perception of implementation between 
employees differs between different groups. Moreover, in the hotel sector, as hotel management relies on employees to deliver superior service, thus, employees could be the foundation of competitive advantages as service quality and customer satisfaction are influenced considerably by the values and actions of hotel employees.

In the past, most hotels had lacked marketing concepts, particularly the concept of internal customers. Based on the findings of this study, in order to enhance employees' job satisfaction the hotel management should strengthen internal marketing activities for employees. These activities would promote employees' job involvement and job satisfaction, which are helpful in achieving employees' organizational commitment. As a result, the concept of internal marketing can become a concrete strategy for improving the quality of service in hotel operations. By providing exceptional service, hotel employees can enhance the image of the hotel and the level of perceived and authentic service quality. Hospitality managers could benefit from these findings as well by adapting strategies to engage and retain highly effective, devoted, and satisfied employees on one hand, and to implement internal marketing principles on the other hand. The more the managers allocate their resources towards internal marketing implementation, the higher the probability of the organization's success.

In addition, hospitality managers should recognize the importance of internal marketing to the survival of hotel operations as competitive pressure increases. As a great deal of time and costs is involved in training employees, the best way to retain outstanding employees and reduce turnover costs and personnel problems is for employers to understand the needs and expectations of their staff, therefore, internal marketing is a practical and sound strategy for increasing organizational commitment.

While the concept of culture has been controversial and interpreted differently by academic authors, the role of culture, in a particular establishment of a service culture was acknowledged as a major dimension for initiation and support of implementation of internal marketing programs. An emphasis should also be placed on the link between the development of a marketing approach to human resource management, how it should be done, and the practical procedures to follow in order to implement it.

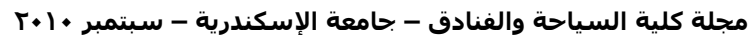


It is noteworthy to mention that, several limitations were encountered in the current study. These included that the study was limited to the category of five-star hotels in Egypt. Future research should explore other categories of hotels as well as other types of service contexts such as restaurants, motels, etc. The present study relied only on four dimensions to measure the internal marketing implementation. Findings of the study were, therefore, indicative rather than conclusive. A field study was conducted at one specific time; a longitudinal study would be useful.

In fact, it should be considered that there is no single, precise prescription for the effective implementation of internal marketing programs. Each hotel operation may have its own approach and style, systems and processes, but the four dimensions identified earlier within the context of this research remain absolutely crucial for the robust launch and continuity of these programs.

This study can be well used to derive many ideas for possible future research such as conducting a research that is exclusively dedicated to search for the factors that affect employees' perceptions of internal marketing, and investigating the impact of management approach on employees' performance in the workplace. Further research attempts should aim at investigating the same research questions but from other perspectives. Moreover, further research in this area may adopt the extension and testing of the four dimensions introduced in this study within different types of organizations, examining employee-customer relationships which might be beneficial to hospitality and customer service organizations. Another line of future research may be considered in investigating the relationship between profitability of the hospitality operation and the implementation of internal marketing programs. It may also include other areas or relationships, for instance, cost reduction, staff turnover and absenteeism reduction. Additionally, investigation of the selection of the channels of disseminating information between the employees and the management and their effectiveness has to be studied. Another considerable area would be assessing the weights of each of the four dimensions of the internal marketing on the employees' perceptions and their effectiveness on the implementation process. 


\section{References}

- Adams, J. (1963). Toward an Understanding of Inequity, Journal of Abnormal and Social Psychology, 67: 422-36.

- Ahmed, P. and Rafiq, M. (2003). Internal Marketing Issues and Challenges, European Journal of Marketing, 37 (9): 1177-86.

- Ahmed, P.; Rafiq, M. and Saad, N. (2002). Internal Marketing and the Mediating Role of Organizational Competencies, European Journal of Marketing, 37 (9): 1221-41.

- Allan, E. and Tyler, T. (1988). The Social Psychology of Procedural Justice. New York: Plenum Press.

- Arnette, B.; Laverie, A. and Mclane, C. (2002). Using Job Satisfaction and Pride as Internal Marketing Tools, Cornell Hotel and Restaurant Administration Quarterly, 34 (2): 87-96.

- Ballantyne, D. (2003). A Relationship Mediated Theory of Internal Marketing, European Journal of Marketing, 37 (9): 1242-60.

- Ballantyne, D.; Christopher, M. and Payne, A. (1995). Relationship Marketing: Bringing Quality, Customer Service and Marketing Together. Oxford: Butterworth-Heinemann/Centre for Services Management, Cranfield School of Management.

- Bansal, S.; Morris, B. and Basu, S. (2001). The Impact of Internal Marketing Activities on External Marketing Outcomes, Journal of Quality Management, 6: 61-76.

- Bell, C. and Zemke, R. (1992). Managing Knock Your Socks off Service. New York; Amacom Publisher.

- Bernstein, S. (2005). Internal Marketing of an ED-based Public Health Initiative, American Journal of Emergency Medicine, 23(3): 411-413.

- Berry, L. (1981).The Employee as a Customer, Journal of Retail Banking, 3: 33-44.

- Bowen, E. and Johnston, R. (1999). Internal Service Recovery: Developing a New Construct, International Journal of Service Industry Management, 10 (2): 118-131.

- Bulgarella, C. (2005). Employee Satisfaction and Customer Satisfaction: Is There a Relationship? A white paper from Guide Star Research.

- Carlzon, J. (1987). Moments of truth. Cambridge: Ballinger Publishing Co.

- Carmouche, R. and Killy, N. (1995). Behavioral Studies in Hospitality Management. London: Chapman and Hall publishers.

- Castellanos-Verdugo, M. and Veerapermal, N. (2009). The EmployeeCustomer Relationship Quality: Antecedents and Consequences in the Hotel Industry, International Journal of Contemporary Hospitality Management, 21 (3): 251-274.

- Chang, C. and Chang, H. (2007). Effects of Internal Marketing on Nurse Job Satisfaction and Organizational Commitment: Example of Medical Centers in Southern Taiwan, Journal of Nursing Research, 15 (4): 2007. 
- Chang, C. and Chang, H. (2009). Perceptions of Internal Marketing and Organizational Commitment by Nurses, Journal of advanced nursing, 65(1): 92-100.

- Crosby, L. and Johnson, S. (2003). Watch What I Do: Leadership Behavior Sends the Strongest Message, Marketing Management, Nov./Dec., 10-11.

- Deal, T. E. and Kennedy, A. A. (1982). Corporate Cultures: The Rites and Rituals of Corporate Life. New York: Perseus Books Publishing.

- Desatnick, R. and Detzel, H. (1993). Managing to Keep the Customer. California: Jossey-Bass Publishers.

- Egyptian Hotel Association (2009). Egyptian Hotel Guide (28 ${ }^{\text {th }}$ Ed.). Cairo: Egyptian Hotel Association.

- Farzad, A.; Nahavandi, N. and Caruana, A. (2008). The Effect of Internal Marketing on Organizational Commitment in Iranian Banks, American Journal of Applied Sciences, 5 (11): 1480-86.

- Foreman, S. and Money, A. (1995). Internal Marketing: Concepts, Measurement, and Application, Journal of Marketing Management, 11: 755-768.

- Forrester, R. (2000). Empowerment: Rejuvenating a Potent Idea, Academy of Management Executive, 14 (3): 67-80.

- Freedman, M. and Montanari, R. (1980). An Integrative Model of Managerial Reward Allocation, The Academy of Management Review, 5 (3): 381-90.

- Gronroos, C. (1982). An Applied Service Marketing Theory, European Journal of Marketing, 16 (7): 30-41.

- Gronroos, C. (1994). From Marketing Mix to Relationship Marketing: Towards a Paradigm Shift in Marketing, Management Decision, 32 (2): 4-20.

- Guest, E. and, Conway, N. (2002). Communicating the Psychological Contract: An Employer Perspective, Human Resource Management Journal, 12 (2): 22-38.

- Hallowell, R.; Schlesinger, A. and Zornitsky, J. (1996). Internal Service Quality, Customer and Job Satisfaction: Linkages and Implications for Management, Human Resource Planning, 19 (2): 20-31.

- Hartline, M. and Ferrell, O. (1996). The Management of Customer Contact Service Employees: An Empirical Investigation, Journal of Marketing, 60: 52-70.

- Heskett, L.; Jones, O.; Loveman, W.; Sasser, E. and Schlesinger, A. (1994). Putting the Service-Profit Chain to Work, Harvard Business Review, 72: 164-174.

- Hogg, G.; Carter, S. and Dunne, A. (1998). Investing in People: Internal Marketing and Corporate Culture, Journal of Marketing Management, 14:879-95.

- Huseman, C. and Hatfield, D. (1990). Equity Theory and the Managerial Matrix, Training and Development Journal, 44 (4): 98-102. 
- James, L.; Joyce, W. and Slocum, J. (1988). Comment: Organizations Do Not Cognize, Academy of Management Review, 13 (1): 129-132.

- Johlke, C. and Duhan, F. (2000). Testing Competing Models of Sales Force Communication, Journal of Personal Selling and Sales Management, 21 (4): 265-77.

- Johlke, C. and Duhan, F. (2001). Supervisor Communication Practices and Boundary Spanner Role Ambiguity, Journal of Managerial Issues, 13 (1): 87-101.

- Kale, H. (2010). Internal Marketing: An Antidote for Macau's Labor Shortage, Gaming Research and Review Journal, 11, (1): 1-11.

- Keller, T. (1994). Technology-Information Processing Fit and the Performance of Rand Project Groups: A Test of Contingency Theory, Academy of Management Journal, 37 (1): 167-179.

- Kotler, P. (2000), Marketing Management. Upper Saddle River, NJ: Prentice Hall.

- Kudo, Y.; Satoh, T.; Hosoi, K.; Miki, T.; Watanabe, M. and Kido, S. (2006). Association Between Intention to Stay on the Job and Job Satisfaction among Japanese Nurses in Small and Medium-Sized Private Hospitals, Journal of Occupational Health, 48(6): 504-513.

- Kusluvan, S.; Kusluvan, Z.; lhan, I. and Buyruk, L. (2010). The Human Dimension: A Review of Human Resources Management Issues in the Tourism and Hospitality Industry, Cornell Hotel and Restaurant Administration Quarterly, 51 (2): 171-214.

- Lawler, E. (2000). Rewarding Excellence. San Francisco: Jossey-Bass.

- Lewis, B. (1991). Customer Care in Service Organizations, Management Decision, 29 (1): 31-34.

- Liljander, V. (2000). The Importance of Internal Relationship Marketing for External Relationship Success. New York: Springer publishers.

- Lings, L. (1999). Balancing Internal and External Market Orientations, Journal of Marketing Management, 15: 239-263.

- Lings, I. and Greenley, E. (2005). Measuring Internal Market Orientation, Journal of Service Research, 7 (3): 290-305.

- Lo, S.; Stalcup, D. and Lee, A. (2010). Customer Relationship Management for Hotels in Hong Kong, International Journal of Contemporary Hospitality Management, 22 (2): 139-159.

- Longbottom, D.; Osseo-Asare, A.; Chourides, P. and Murphy, W. (2006). Real Quality: Does the Future of TQM Depend on Internal Marketing? Total Quality Management and Business Excellence Review, 17(6):709-732.

- Makanjee, C.; Hartzer, Y. and Uys, I. (2006). The Effect of Perceived Organizational Support on Organizational Commitment of Diagnostic Imaging Radiographers, Radiography, 12(2): 118-126.

- Manville, B. and Ober, J. (2003). Beyond Empowerment: Building a Company of Citizens, Harvard Business Review, Jan., 48-53. 
- O'Reilly, C. and Pfeffer, J. (2000). Hidden Value: How Great Companies Achieve Extraordinary Results with Ordinary People. Boston: Harvard Business School Press.

- Parasuraman, A.; Zeithaml, V. and Berry, L. (1991). Refinement and Reassessment of the SERVQUAL Scale, Journal of Retailing, 67 (4):420-451.

- Prahalad and Ramaswamy (2000). Advances in the Internal Marketing Concept: Definition, Synthesis and Extension, Journal of Services Marketing, 14 (6): 449-62.

- Robertson, T. (1994). Personality and Personnel Selection, Journal of Organizational Behavior, 1:75-89.

- Schein, H. (1999). The Corporate Culture Survival Guide: Sense and Nonsense about Culture Change. San Francisco: Jossey-Bass.

- Sihombing, S. and Gustam, M. (2007) The Effect of Internal Marketing on Job Satisfaction and Organizational Commitment: An Empirical Study in a University Setting. Paper presented at the $1^{\text {st }}$ PPM National Conference on Management Research, Jakarta, Indonesia.

- Sirakaya, E.; Kerstetter, D. L. and Mount, D. (1999). Modeling the Selection of High Customer-Contact Personnel: An Application of Behavioral Decision-Making Theory, Journal of Hospitality and Tourism Research, 23 (2):139-159.

- Smidts, A.; Pruynt, T. and Van Riel, B. (2001). The Impact of Employee Communication and Perceived External Prestige on Organizational Identification, Academy of Management Journal, 44 (5): 1051-62.

- Snipes, L.; Oswald, S.; LaTourc, M. and Armenakis, A. (2005). The Effects of Specific Job Satisfaction Facets on Customer Perceptions of Service Quality: An Employee-level Analysis, Journal of Business Research, 27(58): 1330-39.

- Susskind, A.; Borchgrevink, C.; Brymer, R. and Kacmar, K. (2000). Customer Service Behavior and Attitudes among Hotel Managers: A Look at Perceived Support Functions, Standards, and Service Process Outcomes, Journal of Hospitality and Tourism Research, 24(3):373-97.

- Ting, S. (2010). The Effect of Internal Marketing on Organizational Commitment: Job Involvement and Job Satisfaction as Mediators, Educational Administration Quarterly, published online 5 November 2010: 1-30.

- Trimble, D. (2006). Organizational Commitment, Job Satisfaction, and Turnover Intention of Missionaries, Journal of Psychology and Theology, 34(4): 349-60.

- Tsai, Y. and Tang, T. (2008). How to Improve Service Quality: Internal Marketing as a Determining Factor, Total Quality Management and Business Excellence Review, 19(11): 1117-26.

- Turkoz, I. and Akyol, A. (2008). Internal Marketing and Hotel Performance, Anatolia, $\quad$ 19(1): 149-77.

- Varey, R. and Lewis, B. (1999). Internal Marketing: Directions for Management. London: Routledge. 
- Velthouse, B. (1990). Creativity and Empowerment: A Complementary Relationship, Review of Business, 12 (2):13-18.

- Wasmer, D. and Gordon, C. (1991).Using Organizational Culture to Design Internal Marketing Strategies, Journal of Services Marketing, 5 (1):35-46.

- Wildes, V. (2005). Internal Service Quality: Marketing Strategies Can Help to Reduce Employee Turnover for Food Servers, International Journal of Hospitality and Tourism Administration, 6 (2): 1-27.

- Wynne, J. (1993). Power Relationships and Empowerment in Hotels. Employee Relations, 15(2): 42-50. 